\title{
Biodegradation of Sewage Wastewater Using Autochthonous Bacteria
}

\author{
Purnima Dhall, ${ }^{1}$ Rita Kumar, ${ }^{1}$ and Anil Kumar ${ }^{2}$ \\ ${ }^{1}$ Environmental Biotechnology Division, Institute of Genomics and Integrative Biology, Mall Road, Delhi 110007, India \\ ${ }^{2}$ Patent Division, National Institute of Immunology, Aruna Asaf Ali Marg, New Delhi 110067, India
}

Correspondence should be addressed to Anil Kumar, anilk@nii.ac.in

Received 13 September 2011; Accepted 24 October 2011

Academic Editor: Carla Arciola

Copyright () 2012 Purnima Dhall et al. This is an open access article distributed under the Creative Commons Attribution License, which permits unrestricted use, distribution, and reproduction in any medium, provided the original work is properly cited.

\begin{abstract}
The performance of isolated designed consortia comprising Bacillus pumilus, Brevibacterium sp, and Pseudomonas aeruginosa for the treatment of sewage wastewater in terms of reduction in COD (chemical oxygen demand), BOD (biochemical oxygen demand) MLSS (mixed liquor suspended solids), and TSS (total suspended solids) was studied. Different parameters were optimized (inoculum size, agitation, and temperature) to achieve effective results in less period of time. The results obtained indicated that consortium in the ratio of $1: 2$ (effluent : biomass) at $200 \mathrm{rpm}, 35^{\circ} \mathrm{C}$ is capable of effectively reducing the pollutional load of the sewage wastewaters, in terms of COD, BOD, TSS, and MLSS within the desired discharge limits, that is, $32 \mathrm{mg} / \mathrm{L}, 8 \mathrm{mg} / \mathrm{L}, 162 \mathrm{mg} / \mathrm{L}$, and $190 \mathrm{mg} / \mathrm{L}$. The use of such specific consortia can overcome the inefficiencies of the conventional biological treatment facilities currently operational in sewage treatment plants.
\end{abstract}

\section{Introduction}

Until the last 200 years or so, the deterioration of watercourses due to organic pollution was not a serious problem because a relatively small human population lived in scattered communities and the wastes dumped into rivers could be coped with, by the natural self-purification properties. Water pollution became a severe problem with the industrialization of nations, coupled with the rapid acceleration in population growth. Industrialization led to urbanization, with people leaving the land to work in the new factories. Domestic wastes from the rapidly expanding towns and wastes from industrial processes were all poured untreated into the nearest rivers. Effluent waters, which should be removed from settlements and industrial enterprises, are known as sewage. Effluents are classified by their origin as domestic or public sewage, industrial effluents, and atmospheric (rain) run off. The sanitary requirements for the composition and properties of water bodies appreciably limit the discharge of sewage into water bodies.

The term "sewage sludge" or "biosolids" represents the insoluble residue produced during wastewater treatment and subsequent sludge stabilization procedures, such as aerobic or anaerobic digestion [1]. The term sewage refers to the wastewater produced by a community which may originate from three different sources: (a) domestic wastewater, (b) industrial wastewater, and (c) rain water.

Depending on the degree of pollution and the sanitary requirements, all effluents can be either discharged straight into a stream or only after the appropriate treatment (mechanical, chemical, or biological). The sewage should be specially treated before disposal. The method of sewage treatment fall into two groups, mainly, destructive and regenerative methods. Vymazal and Kröpfelová [2] studied the effect of three-stage experimental constructed wetlands for the treatment of sewage. Reported that $94.5 \%$ of BOD and $84.4 \%$ of the COD were removed. Microbial fuel cell with ultra sound pretreatment was assessed by Jiang et al. [3], and it was observed that from raw sewage TCOD removal rate was $11.3 \%$ to $19.2 \%$ and in case of pretreated sludge it was $25 \%$ to $57 \%$. An integrated UASB-sludge digester system was observed in temperate climates [4], and it was seen that, with decrease in temperature, the COD removal decreased from $78 \%$ at $28^{\circ} \mathrm{C}$ to $42 \%$ at $10^{\circ} \mathrm{C}$. On the other hand, Sabry 2008 [5] studied the application of UASB inoculated with flocculent and granular sludge for treating sewage. After $4 \mathrm{~h}$ 


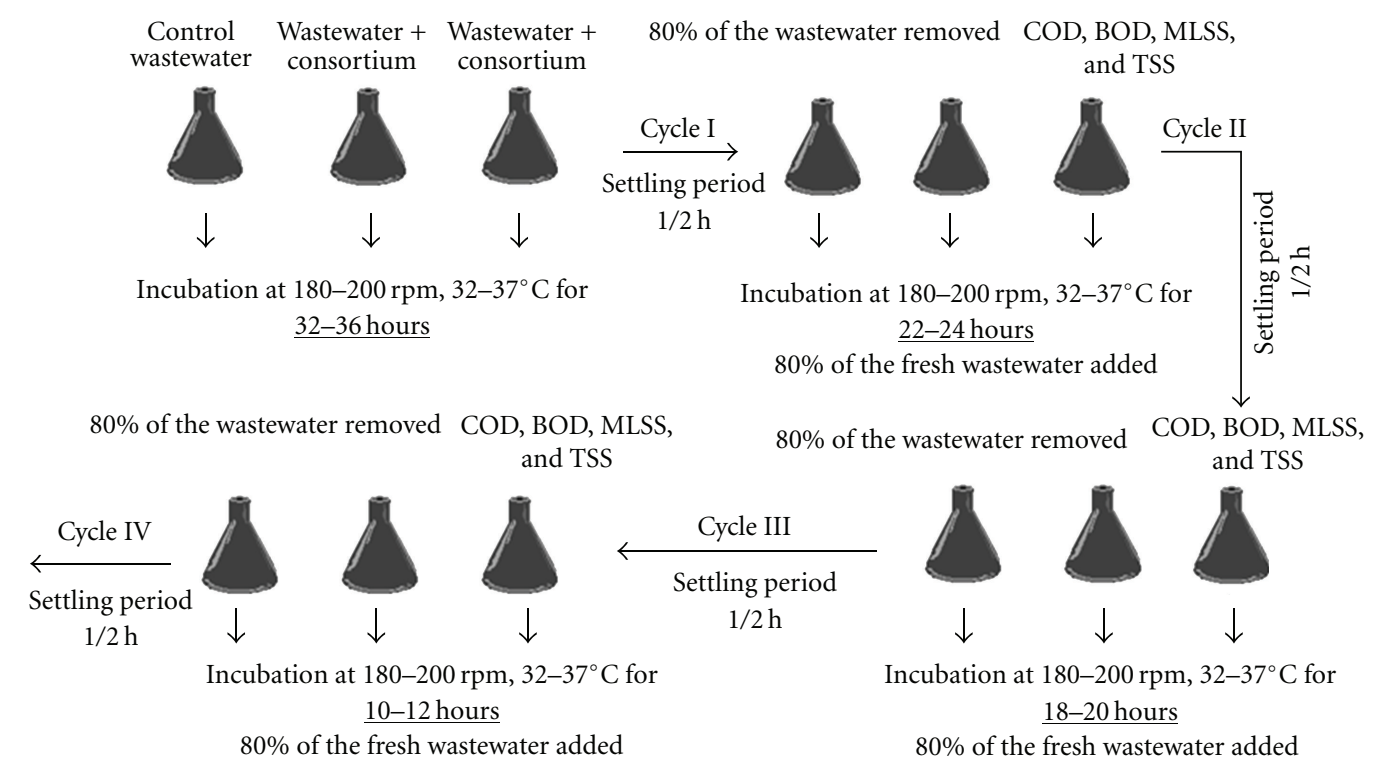

(a)

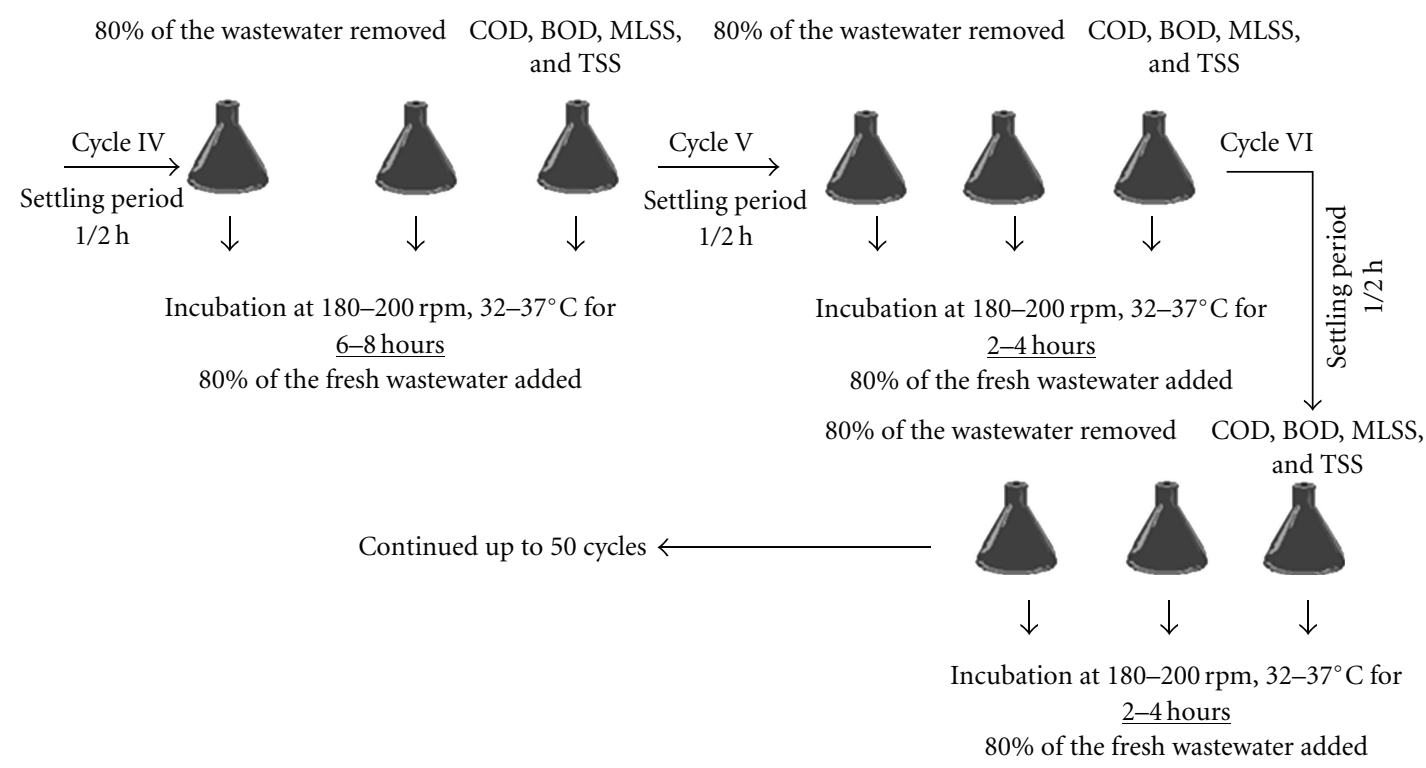

(b)

FIGURE 1: Continuous process for reducing time of degradation there by reducing COD, BOD, MLSS, and TSS.

of retention time, $3-4 \%$ of the COD was removed. Waleed et al. [6] use the cloth media filter membrane bioreactor for treating municipal wastewater, and it was observed that 93-95\% of COD, 99\% of TSS, and turbidity $89-94 \%$ were removed with a retention time of 26.3 days. Garcia et al. [7] studied effects of bed materials on the performance of an anaerobic sequencing batch biofilm reactor that was used for treating the domestic sewage; results were analyzed, and it was revealed that the removal efficiencies for CODtot, CODsus, $\mathrm{BOD}_{5}$, and TSS were $56 \%, 87 \%, 59 \%$, and $81 \%$ for R1 and $58 \%, 90 \%, 60 \%$, and $82 \%$ for R2, respectively. Domestic sewage treatment in a pilot-scale anaerobic sequencing batch biofilm reactor was observed by Sarti et al. [8]. Data obtained from 125 days of treatment was analyzed, and it was seen that, under stable operating conditions after the startup period, the mean values of COD removal efficiency achieved was $66 \%$. The comparative performance of three pilotscale anaerobic sequencing batch reactors treating domestic sewage was evaluated, and it was seen that ASBR1 and ASBR3 reactors operated under mixed liquor recirculation showed nonsatisfactory results, attaining mean values of COD and TSS removals efficiencies of $40 \%$ and $65 \%$, respectively. The ASBR2 operated under mechanical mixing showed better results with average removal efficiencies of $60 \%$ and $80 \%$ for COD and TSS, respectively. Rosal et al. [9] oxidized the effluent from secondary clarifier of an urban sewage treatment plant by using ozone and hydrogen peroxide. The removal efficiency of total organic carbon was no higher than 


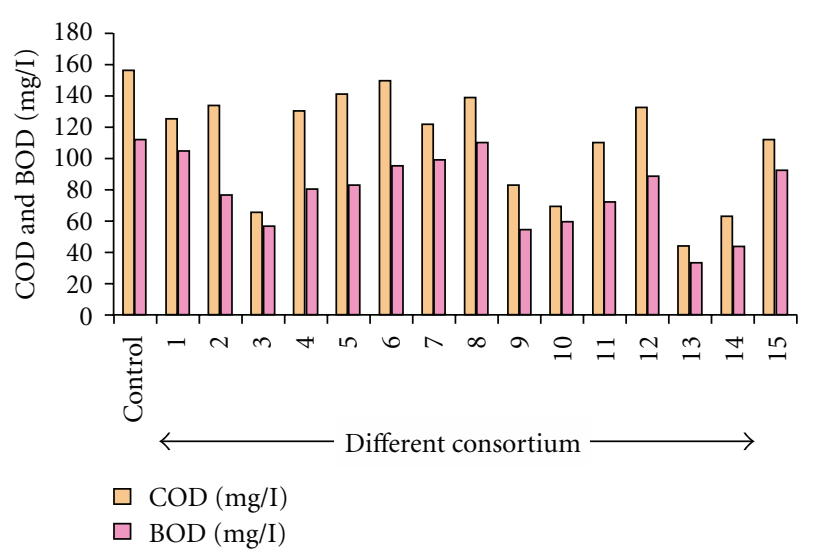

FIgURE 2: Comparison of BOD and COD for 15 consortia.

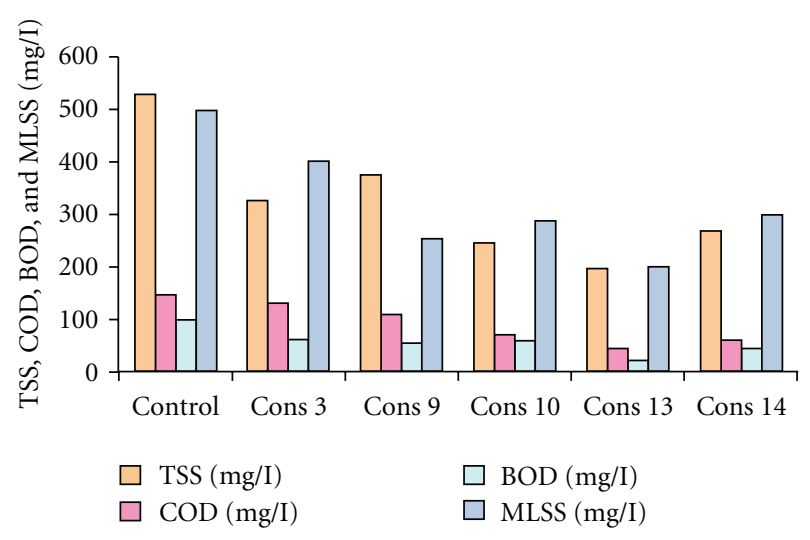

Figure 3: Comparison of TSS, COD, BOD, and MLSS of five selected consortia.

35\%. Elmitwalli et al. [10] use a column packed with clean sheets of reticulated polyurethane foam and fed with either raw sewage, synthetic sewage, or skimmed milk for a short time to evaluate the mechanism of physical entrapment and filtration of particles. The results revealed that clean media were effective in the removal of suspended chemical oxygen demand (COD) (>75\%). Wang [11] found that the removal of colloidal particles was the rate-limiting step in a two-step UASB + EGSB system treating domestic sewage at a HRT of $3+2 \mathrm{~h}$ under low-temperature conditions. He found average removal efficiencies for colloidal COD (CODcol) of $40 \%$ and $49 \%$ at temperatures of $17^{\circ} \mathrm{C}$ and $12^{\circ} \mathrm{C}$, respectively, Yoda et al. [12] reported that the colloidal particles in the influent were very difficult to remove and represented up to $60 \pm 70 \%$ COD of the effluent of an anaerobic fluidized bed (AFB) reactor. Shivarajum [13] describes the photocatalytic degradation of organic pollutants present in the municipal sewage water by using hydrothermally prepared supported photocatalyst. The results obtained represented that the organic pollutants removal efficiency reached upto $97 \%$ for $8 \mathrm{~h}$ irradiation time.

Abdulaziz et al. [14] evaluate the use of membrane bioreactor in combination with activated sludge for the reduction of $\mathrm{BOD}$ and $\mathrm{COD}$ from sewage wastewater. Results showed reduction in $98.5 \%$ of COD and $96 \%$ of BOD. Similar findings were reported by many researchers by using sedimentation, aeration, activated sludge, sand filters and activated carbon [15], and low-cost carbonaceous materials [16] for the reduction of COD and BOD from wastewater. The reduction of COD ranging from 92.1 to $99.05 \%$ and BOD from 98.9 to $99 \%$ was reported at different places. The major disadvantage of using activated sludge for the treatment is generation of large amount of sludge which itself is a major problem for disposal.

The selection of a particular method of treating sewage depends on the composition and properties of the sewage and also on the character and the capacity of the water body. Biological treatment is necessary if organic matter is to be removed from water. Nonetheless, biological treatment offers an economical alternative to physical and chemical treatment methods. It is the most widely used method for removal as well as partial or complete stabilization of biologically degradable substances present in wastewaters. The mechanism underlying biological treatment is the decomposition of finely dispersed matter, colloidal and dissolved substances by metabolism of aerobic microorganisms. The susceptibility of organic substances contained in sewage, to biochemical oxidation coupled with the presence of specific biooxidation agents, that is, microorganisms, is a prerequisite for efficient biodegradation. Specific microorganisms may be required to biodegrade the organic contaminants present in sewage. Employment of single microorganisms may not suffice the purpose. A mixture of microorganisms may have a cumulative effect on increasing the biomass activity, growth efficiency, and enzyme production. In addition, mixed cultures serve to overcome feedback regulation and catabolic repression, as the products of one microorganism act as substrate for the other.

Effective sewage treatment prevents a variety of ailments that can be spread by exposure to pathogens that can be present in untreated sewages and thus helps prevent disease. Discharges of untreated sewage can contaminate ground waters and surface waters used for drinking, recreation, and fish and shellfish fisheries.

Untreated sewage from failed conventional septic systems or sewage discharged directly into the environment can percolate into groundwater, contaminating drinking-water wells with pathogens. The discharge of untreated sewage to streams can spread disease through direct contact, making such streams unfit for forms of recreation that involve skin contact with the water such as swimming and boating. Disease can also spread by indirect (secondary) contact such as through contact with rodents or insects that received primary exposure and in turn harbor the pathogens. Discharged, untreated sewage also can damage the receiving streams' ability to support healthy, living communities of aquatic organisms and can contaminate fisheries.

In the present work, a biotechnological approach has been utilized to treat the sewage wastewater using specific bacteria having biodegradative potential for sewage wastewater. Biodegradation of sewage wastewater was studied in terms of reduction of COD, BOD, MLSS, and TSS. 


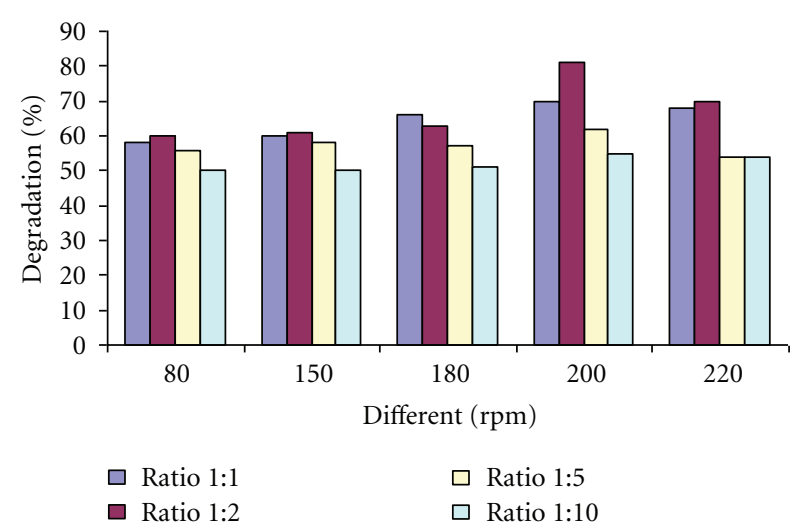

(a)

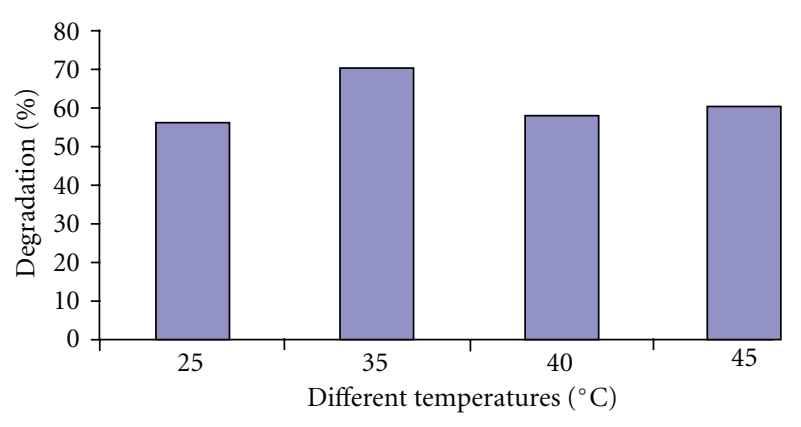

(b)

FIGURE 4: (a) Comparison of percentage degradation of sewage sample after $8 \mathrm{~h}$ at different shaking speed and by using different inoculum size of consortium 13. (b) Comparison of percentage degradation of sewage sample after $4 \mathrm{~h}$ at different incubation temperature.

TABLE 1: The composition of different media designed.

\begin{tabular}{ll}
\hline S. no. & Media composition \\
\hline 1 & $500 \mathrm{~mL}$ soil extract $+2 \%$ Agar \\
2 & $250 \mathrm{~mL}$ soil extract $+250 \mathrm{~mL}$ water $+2 \%$ Agar \\
3 & $250 \mathrm{~mL}$ soil extract $+250 \mathrm{~mL}$ nutrient broth $+2 \%$ agar \\
4 & $500 \mathrm{~mL}$ nutrient agar \\
\hline
\end{tabular}

\section{Material and Methods}

2.1. Collection of Soil Samples. Soil samples were collected in sterile plastic containers from niche areas near the Vasanthkunj sewage treatment plant, New Delhi, for the isolation of bacterial isolates.

2.2. Isolation of Bacteria. Isolation of bacteria was done by using serial dilution method. For bacterial isolation, soil extract and enrichment media were prepared. The soil extract was prepared by dissolving $300 \mathrm{~g}$ of soil sample in $1200 \mathrm{~mL}$ distilled water to make dilution. The solution was centrifuged at $8000 \mathrm{rpm}$ for $15 \mathrm{~min}$ to remove the coarse material, after autoclaving at 15 psi for $15 \mathrm{~min}$. The enrichment media was prepared by transferring $5 \mathrm{~g}$ of soil to a conical flask $(500 \mathrm{~mL})$ containing $125 \mathrm{~mL}$ soil extract and $125 \mathrm{~mL}$ of nutrient broth followed by the addition of $36 \mu \mathrm{L}$ of antifungal. The flask containing enrichment media was incubated at $37^{\circ} \mathrm{C}$ in a rotary shaking incubator at $120 \mathrm{rpm}$ for 2 days. The well-vortexed enrichment media was serially diluted with autoclaved saline water $(0.85 \% \mathrm{NaCl})$ to $10^{-1}$, $10^{-2}, 10^{-3}, 10^{-4}, 10^{-5}$, and $10^{-6}$ dilutions. Diluted sample spread on different designed media plates (Table 1). Plates were incubated at $37^{\circ} \mathrm{C}$ for $16 \mathrm{~h}$.

2.3. Formulation of Consortia. A consortium is a group of specific bacterial isolates which possesses the capability to degrade the components present in the wastewater. For preparation of one consortium, we have used three to four different isolates. Different consortia were formulated randomly primarily on the basis of their morphology, color, size, shape, and so forth.

\subsection{Screening of Different Consortium for Bioremediation.} Different cultures were inoculated in $25 \mathrm{~mL}$ of $\mathrm{NB}$ and incubated overnight at $32-37^{\circ} \mathrm{C}$ and $180-200 \mathrm{rpm}$. These mother cultures were checked by streaking on nutrient agar plates which were then incubated at $32-37^{\circ} \mathrm{C}$. These mother cultures were used for subculturing. $100 \mu \mathrm{L}$ of culture was inoculated into $100 \mathrm{~mL}$ of $\mathrm{NB}$ and incubated at $32-37^{\circ} \mathrm{C}$ under shaking conditions for a period of $16-18 \mathrm{~h}$. The culture was harvested by centrifugation at $4^{\circ} \mathrm{C}$ and $7000 \mathrm{rpm}$ followed by washing twice with sodium phosphate buffer ( $\mathrm{pH}$ 6.8-7.0). The supernatant was discarded and pellets were stored for the further experiments. At the time of experiment, different pellets were resuspended according to the 20 consortia designed and inoculated in the sample and sample flasks were kept in shaking incubator at 180-200 rpm and $32-37^{\circ} \mathrm{C}$ for $32-36 \mathrm{~h}$. After incubation, COD/BOD was estimated according to the procedure mentioned in standard methods (APHA) [17].

2.5. Bioremediation by Using Selected Consortium. Cultures were prepared according to the procedure mentioned above. Pellets were resuspended at the time of experiment, and consortium number 13 was inoculated in the sample, and sample flasks were kept in shaking incubator at 180-200 rpm and $32-37^{\circ} \mathrm{C}$ for $32-36 \mathrm{~h}$. After incubation, the COD, BOD, MLSS, and TSS were estimated according to the procedure mentioned in standard methods (APHA) [17].

2.6. Identification of Selected Bacterial Isolates. The selected organisms of the consortium were identified by 16s rRNA studies at IMTECH, Chandigarh. Morphological, physiological and biochemical tests were also carried out [18] by the identification service of MTCC (Chandigarh, India).

Although 16S rRNA gene is found to be conserved on evolutionary scale, it is still diverse enough for identifying and classifying the eubacteria [19]. For 16S rRNA 
TABLE 2: Morphological characteristics of the identified strains.

\begin{tabular}{|c|c|c|c|}
\hline Test & Bacillus pumilus & Brevibacterium sp. & Pseudomonas aeruginosa \\
\hline \multicolumn{4}{|c|}{ Colony morphology } \\
\hline Margin & Irregular & Irregular & Irregular \\
\hline Elevation & Convex & Convex & Flat \\
\hline Surface & Dull & Glistening & Dull \\
\hline Opacity & Opaque & Opaque & Translucent \\
\hline Gram's reaction & + ve & $+\mathrm{ve}$ & - ve \\
\hline Cell shape & Rods & Cocci/rods & Short rods \\
\hline Endospore & + & - & - \\
\hline Shape & Oval & - & - \\
\hline Motility & + & + & + \\
\hline Fluorescence (UV) & - & - & - \\
\hline
\end{tabular}

TABle 3: Study of physiological features ( $\mathrm{pH}$, temperature, and $\mathrm{NaCl}$ concentration) of identified strains. (-) represents no growth and (+) growth.

\begin{tabular}{|c|c|c|c|}
\hline Tests & $\begin{array}{l}\text { Bacillus } \\
\text { pumilus }\end{array}$ & $\begin{array}{c}\text { Brevibacterium } \\
\text { sp. }\end{array}$ & $\begin{array}{c}\text { Pseudomonas } \\
\text { aeruginosa }\end{array}$ \\
\hline Growth at $\mathrm{pH} 4.0$ & - & - & - \\
\hline pH 5.0 & - & - & + \\
\hline pH 6.8 & + & + & + \\
\hline $\mathrm{pH} 8.0$ & + & + & + \\
\hline pH 9.0 & + & - & + \\
\hline pH 11.0 & - & - & - \\
\hline Growth at $4^{\circ} \mathrm{C}$ & - & - & - \\
\hline $10^{\circ} \mathrm{C}$ & - & - & - \\
\hline $25^{\circ} \mathrm{C}$ & + & + & + \\
\hline $30^{\circ} \mathrm{C}$ & + & + & + \\
\hline $37^{\circ} \mathrm{C}$ & + & + & + \\
\hline $42^{\circ} \mathrm{C}$ & + & + & + \\
\hline $45^{\circ} \mathrm{C}$ & + & + & + \\
\hline $55^{\circ} \mathrm{C}$ & - & - & - \\
\hline $65^{\circ} \mathrm{C}$ & - & - & - \\
\hline \multicolumn{4}{|l|}{$\begin{array}{l}\text { Growth on } \mathrm{NaCl} \\
(\%)\end{array}$} \\
\hline 2.0 & + & + & + \\
\hline 4.0 & + & + & + \\
\hline 7.0 & + & + & - \\
\hline 8.0 & + & - & - \\
\hline 10.0 & + & - & - \\
\hline
\end{tabular}

sequencing, the bacterial culture was inoculated in Luria Bertani broth (Himedia). Overnight-grown bacterial culture was used for total DNA isolation using Genomic DNA Extraction kit. (Real Biotech Corporation). 16 rRNA gene was amplified using universal primers. The PCR reaction mixture contained assay buffer $5 \mu \mathrm{L}$, forward primer $1 \mu \mathrm{L}$, reverse primer $1 \mu \mathrm{L}$, dNTP $1 \mu \mathrm{L}$, template $2 \mu \mathrm{L}$, and tag polymerase $1 \mu \mathrm{L}$, and final total volume was makeup $50 \mu \mathrm{L}$ with milli Q. Polymerase chain reaction was performed in a thermocycler (BIORAD) under the following conditions:
TABLe 4: Biochemical test of identified strains.

\begin{tabular}{|c|c|c|c|}
\hline Tests & $\begin{array}{l}\text { Bacillus } \\
\text { pumilus }\end{array}$ & $\begin{array}{c}\text { Brevibacterium } \\
\text { sp. }\end{array}$ & $\begin{array}{c}\text { Pseudomonas } \\
\text { aeruginosa }\end{array}$ \\
\hline $\begin{array}{l}\text { Growth on } \\
\text { MacConkey agar }\end{array}$ & - & - & + \\
\hline Indole test & - & - & - \\
\hline Methyl red test & - & - & - \\
\hline $\begin{array}{l}\text { Voges Proskauer } \\
\text { test }\end{array}$ & - & - & - \\
\hline Citrate utilization & - & - & + \\
\hline Casein hydrolysis & - & - & + \\
\hline Gelatin hydrolysis & - & - & - \\
\hline Starch hydrolysis & + & - & - \\
\hline Urea hydrolysis & - & - & - \\
\hline Nitrate reduction & - & - & - \\
\hline $\mathrm{H}_{2} \mathrm{~S}$ production & - & - & - \\
\hline Catalase test & + & + & + \\
\hline Oxidase test & - & + & + \\
\hline \multicolumn{4}{|l|}{$\begin{array}{l}\text { Acid production } \\
\text { from carbohydrates }\end{array}$} \\
\hline Salicin & - & - & - \\
\hline Arabinose & - & - & + \\
\hline Galactose & - & - & + \\
\hline Dextrose & + & - & + \\
\hline Meso-Inositol & - & - & - \\
\hline Raffinose & - & - & - \\
\hline Rhamnose & + & - & - \\
\hline Fructose & + & - & + \\
\hline Mannitol & - & - & + \\
\hline Sucrose & + & - & - \\
\hline Xylose & - & - & + \\
\hline
\end{tabular}

denaturation at $94^{\circ} \mathrm{C}$ for $1 \mathrm{~min}$, followed by annealing at $55^{\circ} \mathrm{C}$ for $1 \mathrm{~min}$, and extension at $72^{\circ} \mathrm{C}$ for $2 \mathrm{~min}$, for 35 repeated cycles. Approximately $1500 \mathrm{bp}$ region of the gene was amplified, and the amplification product was gel purified using QIA gel extraction kit and sequenced. The sequence 
TABLE 5: Showing the reduction in time thereby reducing the COD mg/L, BOD mg/L, TSS mg/L, and MLSS mg/L by using consortium 13.

\begin{tabular}{|c|c|c|c|c|c|}
\hline Time & & COD mg/L & BOD mg/L & TSS mg/L & MLSS mg/L \\
\hline \multirow{3}{*}{$36 \mathrm{~h}$} & Control & 196 & 78 & 546 & 425 \\
\hline & Consortium & 48 & 15 & 200 & 170 \\
\hline & $\%$ degradation & 75.5 & 80.8 & 63.4 & 60 \\
\hline \multirow{3}{*}{$24 \mathrm{~h}$} & Control & 172 & 68 & 624 & 600 \\
\hline & Consortium & 40 & 10 & 198 & 225 \\
\hline & $\%$ degradation & 76.7 & 85.3 & 68.3 & 62.5 \\
\hline \multirow{3}{*}{$20 \mathrm{~h}$} & Control & 152 & 62.8 & 569 & 525 \\
\hline & Consortium & 32 & 11 & 185 & 191 \\
\hline & $\%$ degradation & 78.9 & 82.5 & 67.5 & 63.6 \\
\hline \multirow{3}{*}{$12 \mathrm{~h}$} & Control & 150 & 48 & 545 & 700 \\
\hline & Consortium & 35 & 9 & 181 & 250 \\
\hline & $\%$ degradation & 76.7 & 81.3 & 66.8 & 64.3 \\
\hline \multirow{3}{*}{$8 \mathrm{~h}$} & Control & 168 & 59.6 & 600 & 656 \\
\hline & Consortium & 35 & 9.6 & 212 & 230 \\
\hline & $\%$ degradation & 79.2 & 83.9 & 64.7 & 64.9 \\
\hline \multirow{3}{*}{$4 \mathrm{~h}$} & Control & 155 & 55 & 578 & 500 \\
\hline & Consortium & 32 & 8 & 190 & 162 \\
\hline & $\%$ degradation & 79.4 & 85.5 & 67.1 & 67.6 \\
\hline
\end{tabular}

data was analyzed by BLAST and identified based on closest similarity with the reported sequenced data.

2.7. Optimization of Parameters. After the whole experiment, the different parameters like bacterial biomass, shaking speed, temperature, and so forth need optimization. Various parameters (temperature and agitation) were standardized in order to get efficient treatment in less duration.

\subsection{Achieving Short Retention Time by Cyclic Treatment of} Sewage Wastewater. In order to reduce the time of degradation, the consortium was acclimatized as follows. Culture was grown, and pellet was resuspended as mentioned above and inoculated in sample flask. The flask was incubated in shaker at $180-200 \mathrm{rpm}, 32-37^{\circ} \mathrm{C}$ for $32-36 \mathrm{~h}$. After $36 \mathrm{~h}$, the COD was estimated, and, after 30 min of settling, $80 \%$ of the sample was removed and replaced with fresh sample. Flask was again kept for shaking at $200 \mathrm{rpm}$ for 32-36 h, and the COD was estimated after every $4 \mathrm{~h}$. The same process was repeated, and thus the incubation time was gradually reduced to $20,12,8$, and finally to $4 \mathrm{~h}$ (Figure 1 ).

\section{Result and Discussion}

3.1. Isolation and Characteristics of Bacterial Population. 36 bacterial isolates were purified from all the above-mentioned isolation procedure. It was hypothesized that bacteria isolated from their natural habitat have capability of surviving in harsh conditions by developing some catabolic enzymes systems, specific for particular components present in the natural habitat. The isolated colonies were diverse in their morphologies, ranging from small pin-pointed to large sized, smooth margined to wrinkled periphery, shining to dry, and so on. Supplementary Table 1 available online at doi: $10.1100 / 2012 / 861903$ shows the morphological characteristics of those isolated bacterial population obtained during the process of isolation.

3.2. Formulated Consortia. A consortium is a group of specific bacterial isolates which possesses the capability to degrade the components present in the wastewater. For preparation of one consortium, we have used three to four different isolates. 15 different consortia were prepared and checked for their biodegradative potential for sewage wastewater. Different consortia were formulated randomly primarily on the basis of their morphology, color, size, shape, and so forth. The formulated consortia are depicted in Supplementary Table 2 .

3.3. Bioremediation Studies. Formulated consortia were tested for their COD/BOD reduction potential using sewage wastewater sample. The results of these experiments showed that, after $36 \mathrm{~h}$ of incubation, consortia 3 shows percentage degradation of $50 \%$, consortia 9 shows degradation up to $51 \%$, and similarly the rest of the selected consortia 10 , 13 , and 14 show degradation of $46 \%, 70 \%$, and $60.7 \%$ in comparison to other consortia which show degradation in the range of 1.79 to $35.7 \%$. COD/BOD reduction achieved in different flask was mentioned in Figure 2. Five consortia (3, $9,10,13$, and 14) were selected, and the above-mentioned experiment was repeated after $36 \mathrm{~h}$ COD/BOD/MLSS/TSS was estimated, and the results reveal that the consortium 13 gives the best results. It shows percentage degradation of $78 \%$ in comparison of other consortia (Figure 3). The reduction achieved with consortium 13 after $36 \mathrm{~h}$ of incubation in case of COD, BOD, MLSS, and TSS was 148-44 mg/L, 100$22 \mathrm{mg} / \mathrm{L}, 500-199 \mathrm{mg} / \mathrm{L}$, and 525-198 mg/L. The results of 
this cycle with rest of the consortia $(3,9,10$, and 14) show the reduction in COD up to $131 \mathrm{mg} / \mathrm{L}, 110 \mathrm{mg} / \mathrm{L}, 70 \mathrm{mg} / \mathrm{L}$, and $62 \mathrm{mg} / \mathrm{L}$, BOD up to $61 \mathrm{mg} / \mathrm{L}, 52 \mathrm{mg} / \mathrm{L}, 60 \mathrm{mg} / \mathrm{L}$, and $45 \mathrm{mg} / \mathrm{L}$, MLSS up to $400 \mathrm{mg} / \mathrm{L}, 251 \mathrm{mg} / \mathrm{L}, 287 \mathrm{mg} / \mathrm{L}$, and $300 \mathrm{mg} / \mathrm{L}$ and TSS up to $325 \mathrm{mg} / \mathrm{L}, 374 \mathrm{mg} / \mathrm{L}, 244 \mathrm{mg} / \mathrm{L}$, and $269 \mathrm{mg} / \mathrm{L}$, respectively. Consortium 13 was selected for further studies.

3.4. Identification of Cultures. Strains were identified on the basis of physiological, morphological, biochemical, and 16rRNA techniques performed at MTCC (Chandigarh). Strains of the selected consortium 13 were identified as Bacillus pumilus, Brevibacterium sp, and Pseudomonas aeruginosa.

Morphological characteristics (margin, elevation, surface, opacity, gram's reaction, cell shape, endospore, position, shape, motility, and fluorescence) of the identified strains is depicted in Table 2.

Physiological tests and various biochemical tests were also performed, and the results showed that Bacillus pumilus, MTCC (5305) is aerobic in nature, gram positive, motile, shows its growth from 25 to $45^{\circ} \mathrm{C}$, capable to starch hydrolysis, and catalase positive. Brevibacterium sp. (MTCC 5306 ) is aerobic in nature, gram positive, motile, shows its growth from 25 to $45^{\circ} \mathrm{C}$ catalase and oxidase positive. Pseudomonas aeruginosa (MTCC 5307) is aerobic in nature, gram negative, motile, shows its growth from 25 to $42^{\circ} \mathrm{C}$, this bacterium capable to utilize the citrate and hydrolyze casein, catalase, and oxidase positive (Tables 3 and 4).

3.5. Optimization of Parameters by Using Consortium 13. Effect of inoculum size and Agitation: the effect of biomass on the COD reduction ability of consortium was studied. Different effluent: biomass ratios of $1: 1,1: 2,1: 5$, and $1: 10$ were tried. Agitation was tested simultaneously; flasks were incubated at different rpm ( $80 \mathrm{rpm}, 150 \mathrm{rpm}, 180 \mathrm{rpm}$, $200 \mathrm{rpm}$, and $220 \mathrm{rpm}$ ). Results suggested that consortium 13 produced the best results when used in the $1: 2$ effluent: biomass ratio and incubated at $200 \mathrm{rpm}$. The reduction in COD was observed up to $79 \%$ after $36 \mathrm{~h}$ of incubation period (Figure 4(a)).

Temperature. Different temperatures were also studied for better COD reduction. The results reveal that better COD reduction could be achieved in the flask incubated at $35^{\circ} \mathrm{C}$ as compared to the other flasks incubated at $25^{\circ} \mathrm{C}, 40^{\circ} \mathrm{C}$, and $45^{\circ} \mathrm{C}$ (Figure 4(b)).

3.6. Cyclic Treatment of Sewage Wastewater. The selected consortium comprises 3 bacterial isolates found to be capable of reducing COD, BOD, and TSS of sewage wastewater. In order to reduce the time of degradation, the consortium was acclimatized. Table 5 shows the reduction in COD, BOD, and TSS by using selected consortium 13 while reducing time of incubation from $36 \mathrm{~h}$ to $4 \mathrm{~h}$. The reduction achieved after $36 \mathrm{~h}$ in case of COD, BOD, MLSS, and TSS was from 196$48 \mathrm{mg} / \mathrm{L}, 78-15 \mathrm{mg} / \mathrm{L}, 425-170 \mathrm{mg} / \mathrm{L}$, and $546-200 \mathrm{mg} / \mathrm{L}$. After 30 min of settling, $80 \%$ of wastewater was removed and fresh $80 \%$ was added, and the sample was incubated for $24 \mathrm{~h}$.
The results of this cycle show the reduction in COD from 172 to $40 \mathrm{mg} / \mathrm{L}$, BOD from 68 to $10 \mathrm{mg} / \mathrm{L}$, MLSS 600 to $225 \mathrm{mg} / \mathrm{L}$, and TSS from 624 to $198 \mathrm{mg} / \mathrm{L}$. In the same manner, settling was done for $30 \mathrm{~min}$ and incubation time was further reduced to $20 \mathrm{hr}$. Estimation revealed the reduction $152-$ $32 \mathrm{mg} / \mathrm{L}, 62.8-11 \mathrm{mg} / \mathrm{L}, 525-191 \mathrm{mg} / \mathrm{L}$, and $569-190 \mathrm{mg} / \mathrm{L}$ in COD, BOD, MLSS, and TSS, respectively. This reduction in incubation time was carried on further from $12 \mathrm{~h}$ to 8 and then finally to $4 \mathrm{~h}$. The final results show that the percentage degradation was $79 \%$ (155-32 mg/L), 85.5\% (55$8 \mathrm{mg} / \mathrm{L}), 67.6 \%(500-162 \mathrm{mg} / \mathrm{L})$, and $67.1 \%(578-190 \mathrm{mg} / \mathrm{L})$ for COD, BOD, MLSS, and TSS, respectively, after $4 \mathrm{~h}$ of incubation.

\section{Conclusion}

The selected formulated bacterial consortium comprising of the isolated bacterial strains acts in a synergistic way and is capable of degrading the easily assimilable organic compounds present in sewage wastewater. This consortium is capable of effectively reducing the pollutional load of the sewage wastewaters, in terms of COD, BOD, MLSS, and TSS within the desired discharge limits, that is, $32 \mathrm{mg} / \mathrm{L}, 8 \mathrm{mg} / \mathrm{L}$, $162 \mathrm{mg} / \mathrm{L}$, and $190 \mathrm{mg} / \mathrm{L}$. The use of such specific consortia can overcome the inefficiencies of the conventional biological treatment facilities currently operational in sewage treatment plants.

\section{Acknowledgments}

The authors acknowledge the financial help provided by the MoEF (Ministry of Environment and Forest), Government of India. They are also thankful to CSIR for providing necessary infrastructure.

\section{References}

[1] S. Arcak, A. Karaca, E. Erdogan, and C. Türkmen, "A study on potential agricultural use of sewage sludge of Ankara wastewater treatment plant," in Proceedings of the International Symposium on Desertification, pp. 345-349, The Soil Science Society of Turkey, Konya, Turkey, 2000.

[2] J. Vymazal and L. Kröpfelová, "A three-stage experimental constructed wetland for treatment of domestic sewage: first 2 years of operation," Ecological Engineering, vol. 37, no. 1, pp. 90-98, 2011.

[3] J. Jiang, Q. Zhao, L. Wei, K. Wang, and D. J. Lee, "Degradation and characteristic changes of organic matter in sewage sludge using microbial fuel cell with ultrasound pretreatment," Bioresource Technology, vol. 102, no. 1, pp. 272-277, 2011.

[4] B. Lew, I. Lustig, M. Beliavski, S. Tarre, and M. Green, "An integrated UASB-sludge digester system for raw domestic wastewater treatment in temperate climates," Bioresource Technology, vol. 102, no. 7, pp. 4921-4924, 2011.

[5] T. Sabry, "Application of the UASB inoculated with flocculent and granular sludge in treating sewage at different hydraulic shock loads," Bioresource Technology, vol. 99, no. 10, pp. 40734077, 2008.

[6] M. Waleed, A. Saber, and S. A. El-Shafai, "Use of cloth-media filter for membrane bioreactor treating municipal wastewater," Bioresource Technology, vol. 102, no. 3, pp. 2193-2198, 2011. 
[7] M. L. Garcia, K. R. Lapa, E. Foresti, and M. Zaiat, "Effects of bed materials on the performance of an anaerobic sequencing batch biofilm reactor treating domestic sewage," Journal of Environmental Management, vol. 88, no. 4, pp. 1471-1477, 2008.

[8] A. Sarti, B. S. Fernandes, M. Zaiat, and E. Foresti, "Anaerobic sequencing batch reactors in pilot-scale for domestic sewage treatment," Desalination, vol. 216, no. 1-3, pp. 174-182, 2007.

[9] R. Rosal, A. Rodríguez, J. A. Perdigón-Melón, A. Petre, and E. García-Calvo, "Oxidation of dissolved organic matter in the effluent of a sewage treatment plant using ozone combined with hydrogen peroxide (O3/H2O2)," Chemical Engineering Journal, vol. 149, no. 1-3, pp. 311-318, 2009.

[10] T. A. Elmitwalli, M. van Dun, H. Bruning, G. Zeeman, and G. Lettinga, "The role of filter media in removing suspended and colloidal particles in an anaerobic reactor treating domestic sewage," Bioresource Technology, vol. 72, no. 3, pp. 235-242, 2000.

[11] K. Wang, Integrated anaerobic and aerobic treatment of sewage, Ph.D. thesis, Wageningen Agricultural University, Wageningen, The Netherlands, 1994.

[12] M. Yoda, M. Hattori, and Y. Miyaji, "Treatment of municipal wastewater by anaerobic Fluidized bed: behaviour of organic suspended solids in anaerobic treatment of sewage," in Proceedings of the Seminar/Workshop on Anaerobic Treatment of Sewage, pp. 161-197, Amherst, Mass, USA, 1985.

[13] H. P. Shivarajum, "Removal of organic pollutants in the municipal sewage water by Tio2 based Heterogeneous Photocatalysis," International Journal of Environmental Sciences, vol. 1, no. 5, pp. 911-923, 2011.

[14] S. A. Abdulaziz, G. Hussain, and O. A. Al-Harbi, "Use of membrane bio-reactor and activated sludge to remove COD and BOD from sewage water in Saudi Arabia," Reasearch Journal of Environmental Science, vol. 5, no. 1, pp. 68-76, 2011.

[15] S. A. Al-Jlil, "COD and BOD reduction of domestic wastewater using activated sludge, sand filters and activated carbon in Saudi Arabia," Biotechnology, vol. 8, no. 4, pp. 473-477, 2009.

[16] R. Devi and R. P. Dahiya, "Chemical oxygen demand (COD) reduction in domestic wastewater by fly ash and brick kiln ash," Water, Air, and Soil Pollution, vol. 174, no. 1-4, pp. 33-46, 2006.

[17] Standard Methods for the Examination of Water and Wastewater, American Public Health Association/American Water Works Association/Water Environment Federation, Washington, DC, USA, 20th edition, 1998.

[18] G. Colman, E. Fox, R. J. Gross, B. Holmes, P. A. Jenkins, and D. M. Jones, "Theory and practice of bacterial identification," in Cowan and Steel's Manual for the Identification of Medical Bacteria, G. I. Barrow and R. K. A. Feltham, Eds., p. 21e44, Cambridge University Press, Cambridge, UK, 1993.

[19] R. I. Amann, W. Ludwig, and K. H. Schleifer, "Phylogenetic identification and in situ detection of individual microbial cells without cultivation," Microbiological Reviews, vol. 59, no. 1, pp. 143-169, 1995. 

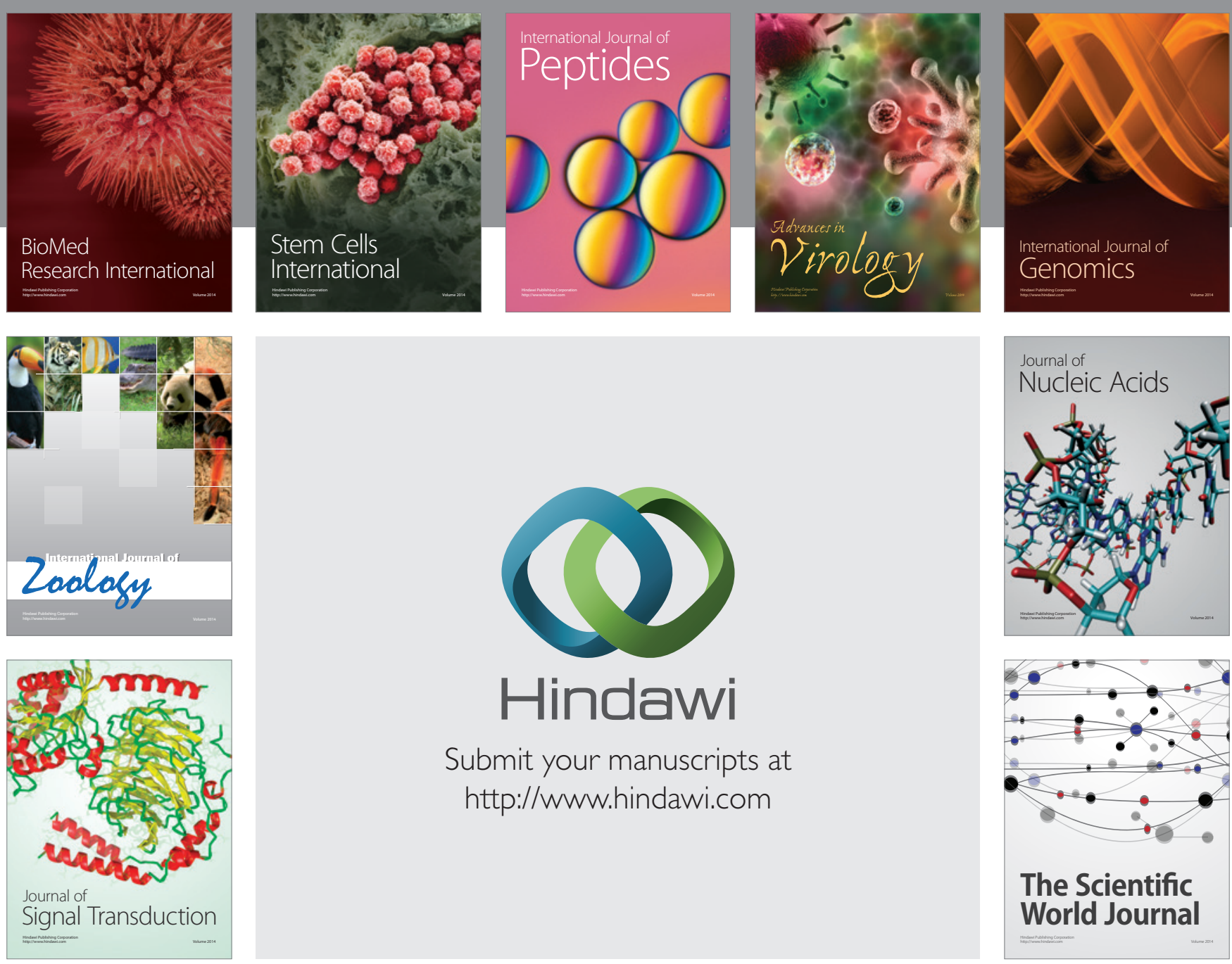

Submit your manuscripts at

http://www.hindawi.com
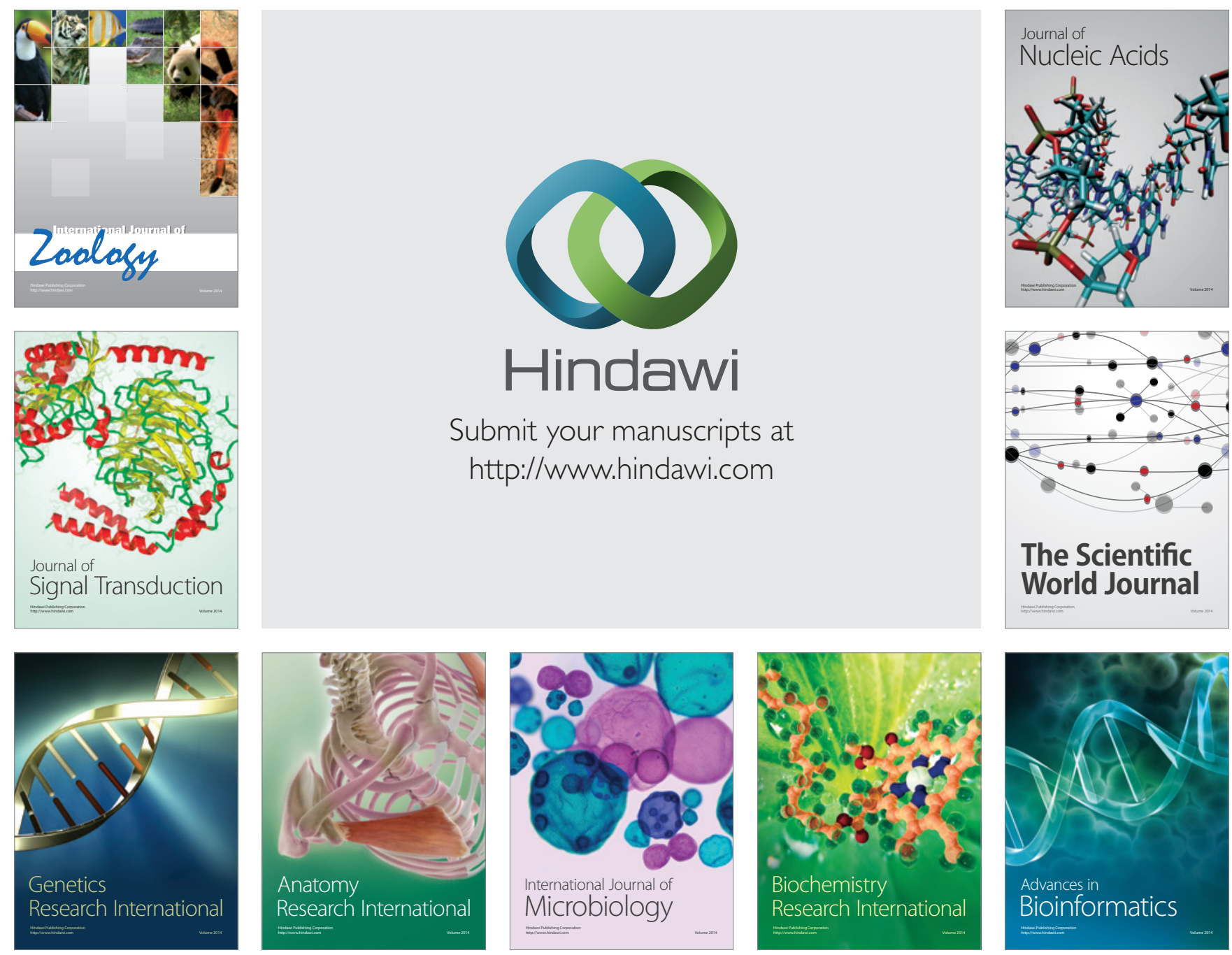

The Scientific World Journal
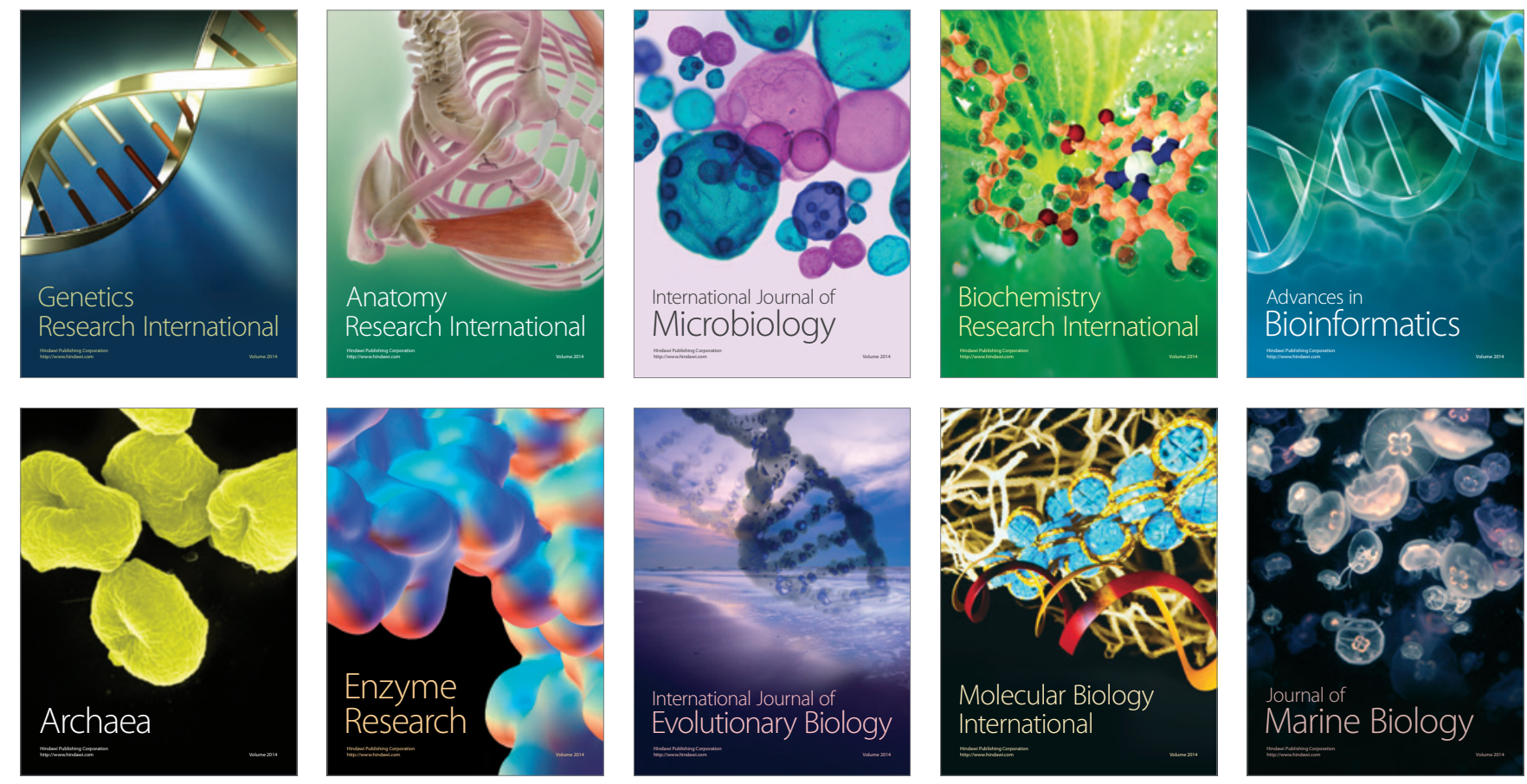